Indonesian Journal of Biotechnology, December 2015

Vol. 20, No. 2, pp.108-116

\title{
Characterization of Aspergillus Niger $65 i 6$ lipase from solid-state fermentation using Jatropha seed cake medium
}

\author{
Chusnul Hidayat ${ }^{1^{*}}$, Sari Darmasiwi ${ }^{2}$, Maulina Nurikasari ${ }^{3}$, \\ Muhammad Nur Cahyanto ${ }^{1}$
}

\footnotetext{
${ }^{1}$ Department of Food and Agricultural Product Technology, Universitas Gadjah Mada, Jl. Flora, Bulaksumur, Yogyakarta, Indonesia

${ }^{2}$ Department Biology, Universitas Gadjah Mada, Jl. Teknika Selatan, Sekip Utara, Yogyakarta

${ }^{3}$ Graduate School of Biotechnology, Universitas Gadjah Mada, Jl. Teknika Utara, Barek, Yogyakarta, Indonesia
}

\begin{abstract}
Jatropha curcas seed cake contains a high amount of protein, and consequently has very high potential as a medium for lipase production. The objective of this research was to characterize lipase from Aspergillus niger 6516, which was produced by solid-state fermentation on Jatropha curcas seed cake as the medium. The effects of $\mathrm{pH}$ and temperature on enzyme activity were evaluated, along with substrate specificity and enzyme stability. Fermentation was performed at a water concentration of $63 \%$ and temperature of $30{ }^{\circ} \mathrm{C}$ for 7 days. The results showed that the optimum $\mathrm{pH}$ and temperature for Aspergillus niger 6516 lipase activities were 8.0 and $40{ }^{\circ} \mathrm{C}$, respectively. The lipase had the substrate specificity to hydrolyze long-chain fatty acids and was stable in polar organic solvents. The lipase had a molecular weight, $\mathrm{Km}$ and $\mathrm{v}_{\max }$ about $19 \mathrm{kDa}, 0.27 \mu \mathrm{mol} / \mathrm{ml}$, and $52.63 \mu \mathrm{mol} / \mathrm{ml} / \mathrm{min}$, respectively. The results also suggested that the produced lipase from Aspergillus niger 6516 was an alkaline lipase. Based on these results, we conclude that Jatropha seed cake is a suitable medium for lipase production.
\end{abstract}

Keywords: Lipase, Aspergillus niger, jatropha cake, solid state fermentation

\section{Introduction}

Lipase (E.C.3.1.1.3) is an enzyme that catalyzes both the hydrolysis of esters (Bora et al., 2011; Cho et al., 2011), and under certain conditions the synthesis of esters (Akanbi et al., 2015). Since the reaction is reversible, it can be used in many applications, such as food, chemicals, pharmaceuticals, biosensors, pesticides, leather, cosmetics, biodiesel, and detergents (Akanbi et al., 2015; Hasan et al., 2006; Berchmans and Hirata, 2008; Bisen et al., 2010; Zang et al., 2011).

\footnotetext{
* Corresponding Author:

Chusnul Hidayat

Department of Food and Agricultural Product Technology, Universitas Gadjah Mada, Jl. Flora, Bulaksumur, Yogyakarta, Indonesia 55281.

Tel./fax: +62 274549650 .

E-mail: chusnul@gadjahmada.edu
}

Lipase can be found in plants, bacteria, and fungi. Plant lipase has been produced from Jatropha seeds (Abigor, 2002; Hidayat et al., 2014), palm oil (Ebongue et al., 2006), and rice bran (Chong et al., 2007; Hidayat et al., 2014). Bacterial lipases have been obtained from Bacillus coagulans and Pseudomonas aeruginosa (Alkan, 2007; Mahanta et al., 2008). Meanwhile, yeast lipase has been produced mostly from Candida rugosa and Candida antarctica (Bussamara, 2010). Most lipases produced by fungi are from Rhizopus sp., Aspergillus sp., Penicillium sp., and Rhizomucor sp. (Cihangir and Sarikaya, 2004; Gutarra et al., 2009; Mahapatra et al., 2011; Damaso et al., 2008; Silva et al., 2011; Kempka et al., 2008). In general, the optimum $\mathrm{pH}$ for bacterial lipase is neutral or alkaline, and it is more thermostable than plant lipase. Yeast lipase is mostly in the form of isoenzyme and has a 
molecular weight of 33-65 kDa (Vokhlu and Kour, 2006).

In enzyme production, the cost of medium should also be taken into consideration. Agro-industrial wastes including wheat bran (Mahadik et al., 2002; Mahapatra et al., 2011), sugarcane bagasse (Rodriguez et al., 2006), and babassu cake (Silva et al., 2011) have been used as alternative media for the production of lipase using solid-state fermentation (SSF). Jatropha curcas seed cake is the by-product of oil extraction, containing a high concentration of protein and carbohydrates. It is very potential to be used as a source medium for $\mathrm{C}$ and $\mathrm{N}$ in the production of enzymes, especially lipase. Mahanta et al. (2008) used Jatropha curcas seed cake as a medium for lipase production from the bacteria Pseudomonas aeruginosa. However, fungi are much more suitable for solid-state fermentation since it creates a restricted condition that is almost similar to their natural environment.

Most fungi lipases have been produced using solid-state fermentation, such as that produced by Penicillium restrictum (Gombert et al., 1999), Aspergillus niger (Kamini et al., 1998; Mahadik et al., 2002), and Rhizopus oligosporus (ul-Haq et al., 2002). It is a fermentation method that involves the growth of microorganisms in moist solidsubstrate in the absence of free flowing water. The benefit of this low water requirement is a method that is simple, economical, and lower in energy demand and contamination risk, as well as superior in productivity.

In addition to the medium and fermentation conditions, lipase production also depends on the isolate. Microbial selections are very important, as well. The objective of this research was to investigate the characteristics of lipase from the selected fungi Aspergillus niger 6516 using solid-state fermentation on Jatropha curcas seed cake as the medium. The optimum $\mathrm{pH}$ and temperature for lipase activity, substrate specificity, and stability in organic solvents, were evaluated. Partial purification of the enzyme using anion exchange chromatography was also performed.

\section{Materials and Methods \\ Fungal strain}

Aspergillus niger 65I6 was obtained from the Laboratory of Biotechnology, Department of Food and Agricultural Product Technology, Universitas Gadjah Mada, Indonesia. The strain was maintained by monthly transfers to potato agar slant tubes, incubated at $30^{\circ} \mathrm{C}$ and stored at $4{ }^{\circ} \mathrm{C}$.

\section{Materials}

Jatropha seeds and palm oil were obtained from a local supplier in the Special Region of Yogyakarta, Indonesia. Methanol, pyridine, $\mathrm{NaH}_{2} \mathrm{PO}_{4}, \mathrm{Na}_{2} \mathrm{HPO}_{4}, \mathrm{Cu}$ acetate, sodium acetate, acetic acid, TRIS, acetone, n-hexane, and $\mathrm{HCl}$ were obtained from Merck KGaA (Germany). Olive oil, isooctane, and tributyrin were obtained from Sigma-Aldrich (USA), and oleic acid from AppliChem (USA).

\section{Fermentation Conditions}

The medium for lipase production was prepared by pressing the Jatropha seeds using a press machine (Paul Weber Maschinen GmBh, Germany) at $140.6 \mathrm{~kg} / \mathrm{cm}$. The pressed Jatropha seed cake was ground and then defatted using an n-hexane solvent (1:6). The resulting defatted cake was dried and further ground into Jatropha seed powder, ready for use as a solid-state fermentation medium.

Fermentation was carried out according to the method of Falony et al. (2006). Medium containing $5 \mathrm{~g}$ of Jatropha cake powder and $2 \%$ olive oil $(\mathrm{v} / \mathrm{w})$ was autoclaved at $121^{\circ} \mathrm{C}$, and further inoculated with fungal cultures. Inoculum concentration was $10^{7}$ spores/ $\mathrm{ml}$ while water concentration was $63 \%$. The medium was incubated at room temperature for 7 days.

\section{Enzyme Extraction}

Extraction of lipase was performed according to the method of Gutarra et al. 
Hidayat et al.

(2009). Fermented medium was added into $0.1 \mathrm{M}$ extraction buffer ( $5 \mathrm{ml} / \mathrm{g}$ substrate) and mixed in a rotary shaker at $30^{\circ} \mathrm{C}$ and 100 rpm for $20 \mathrm{~min}$. Solid phase was separated by filtration whereas liquid phase was further centrifuged at $3000 \mathrm{rpm}$ for $30 \mathrm{~min}$. The supernatant was used as a crude enzyme and stored at $-18^{\circ} \mathrm{C}$ for further analysis.

\section{Enzyme Purification}

The crude enzyme was added into an anion exchange column and washed with an adsorption buffer. The adsorbed lipase was eluted with an elution buffer containing 1 $\mathrm{M} \mathrm{NaCl}$, after which it was stored at $-18^{\circ} \mathrm{C}$ and used as a partially purified enzyme for further analysis.

\section{Effect of $p H$ on Lipase Activity}

The effect of $\mathrm{pH}$ on lipase activity was studied by extracting the fermented medium with buffers at various $\mathrm{pH}$ levels ( $\mathrm{pH} 4.0-9.0)$, namely acetate buffer $(\mathrm{pH}$ 4.0-5.0), phosphate buffer ( $\mathrm{pH} 6.0-7.0)$, and Tris-HCl buffer ( $\mathrm{pH} 8.0-9.0)$. The buffer was added into fermented seed cake $(5 \mathrm{~mL} / \mathrm{g}$ substrate) and mixed in a rotary shaker at 30 ${ }^{\circ} \mathrm{C}$ and $100 \mathrm{rpm}$ for $20 \mathrm{~min}$. The solid phase was separated by filtration and supernatant was centrifuged at $3000 \mathrm{rpm}$ for $30 \mathrm{~min}$. The supernatant was used as a crude enzyme. A partially purified enzyme was obtained by anion exchange purification. Lipase activity was further determined.

\section{Effect of Temperature on Lipase Activity}

The fermented medium was extracted with a buffer ( $5 \mathrm{~mL} / \mathrm{g}$ substrate) at $\mathrm{pH}$ 8.0. Partially purified lipase was obtained by anion exchange purification step. Furthermore, the crude and partially purified lipase activities were determined after incubation at various temperatures $\left(30-70^{\circ} \mathrm{C}\right)$ for $20 \mathrm{~min}$.

\section{Substrate specificity}

The substrate specificity of lipase was determined by incubating the crude enzyme in different kinds of substrate (olive
I.J. Biotech, Vol. 20, No. 2

oil, Jatropha oil, palm oil, and tributyrin) in iso-octane $(60 \% \mathrm{w} / \mathrm{v})$. The reaction mixture was incubated at $40{ }^{\circ} \mathrm{C}$ for 60 minutes. The reaction was stopped by placing the reaction mixture in an ice bath. About 200 $\mu \mathrm{L}$ aliquots were taken and added into the reaction tubes containing $1800 \mu \mathrm{L}$ iso-octane and $400 \mu \mathrm{L}$ of $5 \%$ cupric acetate pyridine $\mathrm{pH}$ 6.0. The content of free fatty acids in the mixtures was determined by comparing the absorbance of the mixture with standard curve of free fatty acids at $715 \mathrm{~nm}$. One unit of lipase activity was defined as the amount of enzyme that released $1 \mu \mathrm{mol}$ of fatty acids from acylglycerol per min.

\section{Lipase Stability in Organic Solvents}

Crude lipases were diluted in various solvents (methanol, acetone, and n-hexane) at a ratio of 1:1. Each mixture was then incubated in a waterbath at $37^{\circ} \mathrm{C}$ at $60 \mathrm{rpm}$ for 1 hour (Pera et al., 2006). The remaining lipase activity in the solvent was then determined. Lipase stability was determined by comparing the activity of the lipase in the solvents and buffer.

\section{Hydrolytic Activity Analysis}

Lipase activity was determined according to Marseno et al. (1998). The substrate (60\% olive oil in iso-octane) was prepared by mixing $60 \mathrm{ml}$ of olive oil with $40 \mathrm{ml}$ of iso-octane. The reaction was started by the addition of $200 \mu \mathrm{l}$ of enzyme to $2 \mathrm{ml}$ of the substrate. The mixture was incubated in a $30{ }^{\circ} \mathrm{C}$ shaker water bath at $120 \mathrm{rpm}$ for $20 \mathrm{~min}$. The reaction was stopped by placing the mixture in an ice bath. About $200 \mu \mathrm{l}$ was added into reaction tubes containing $1800 \mu \mathrm{l}$ of iso-octane and $400 \mu \mathrm{l}$ of $5 \%$ cupric acetate pyridine ( $\mathrm{pH}$ 6.0). The content of free fatty acids in the mixtures was determined by comparing the absorbance of the mixture with the standard curve of free fatty acids at $715 \mathrm{~nm}$. One unit of lipase activity was defined as the amount of enzyme that released $1 \mu \mathrm{mol}$ of fatty acid per min. 


\section{Esterification Activity Analysis}

About $4 \mathrm{ml}$ of medium containing oleic acid $(0,5 \mathrm{M})$ and methanol $(0,5 \mathrm{M})$ (molar ratio 1:1) in iso-octane was added into an Erlenmeyer flask, and adding $200 \mu \mathrm{l}$ of enzyme solution started the reaction. The mixture was incubated in a $30{ }^{\circ} \mathrm{C}$ water bath shaker at $120 \mathrm{rpm}$ for $20 \mathrm{~min}$, after that the reaction was stopped by placing the reaction mixture in an ice bath for $5 \mathrm{~min}$. An aliquot of $200 \mu \mathrm{l}$ was taken and added to a mixture of $1800 \mu 1$ of iso-octane and $400 \mu \mathrm{l}$ cupric-acetate pyridine (CAP) ( $\mathrm{pH}$ 6.0). Free fatty acids in the mixture were determined in the same manner as that described for the hydrolytic activity assay. One unit of lipase activity was defined as the amount of of free fatty acid $(\mu \mathrm{mol})$ that reacted with methanol per min.

\section{Results and Discussion}

Composition of Jatropha Solvent-defatted Press cake

Table 1 shows the composition of the Jatropha press cake and the solvent-defatted press cake. The dried Jatropha seeds were containing of $56.81 \%$ oil, which decreased $50 \%$ after oil extraction using a hydraulic press machine (Table 1). Furthermore solvent-based extraction of oil in the Jatropha press cake using n-hexane resulted in lower oil content $(0.55 \%)$, as well as higher protein content $(42.58 \%)$ because of the released

Table 1. Composition of Jatropha press cake and solventdefatted Jatropha press cake.

\begin{tabular}{cccc}
\hline No. Composition & $\begin{array}{c}\text { Press cake } \\
\mathbf{( \% )}\end{array}$ & $\begin{array}{c}\text { Solvent- } \\
\text { defatted press } \\
\text { cake (\%) }\end{array}$ \\
\hline 1 & Oil (\%) & 28.68 & 0.55 \\
2 & Protein (\%) & 30.55 & 42.58 \\
3 & Water (\%) & 10.43 & 15.59 \\
\hline
\end{tabular}

protein from the seeds. As a consequence, nitrogen content in the medium increased without organic or inorganic nitrogen compounds being added to the fermentation medium.

\section{Partial Purification of Lipase Using Anion Exchange Chromatography}

Partial purification of Aspergillus niger 65 I6 lipase was performed in order to achieve higher specific activity in the lipase. Table 2 shows the results of partial purification using anion exchange chromatography. One step purification using anion exchange chromatography resulted an increasing in specific activity from $34.82 \mathrm{U} / \mathrm{mg}$ to 421.97 $\mathrm{U} / \mathrm{mg}$. These results indicate that one step purification resulted in high enzyme purity, in which the purification factor was 12.1 and lipase yield $86.11 \%$.

\section{Effect of pH on Aspergillus niger 5I6 Lipase Activity}

Fig. 1 shows that hydrolytic lipase activities increased 4.5 times with an increase in buffer $\mathrm{pH}$ from 4.0 to 8.0. Further increase to 9.0, however, resulted in lower hydrolytic activity by about 1.5 times. Lipase activity was not significantly different at buffer pHs of 5.0 to 7.0. Meanwhile, esterification activity increased about 4.9 times when the buffer $\mathrm{pH}$ increased from 6.0 to 8.0, but again decreased when the buffer $\mathrm{pH}$ was raised to 9.0. Therefore, the optimum buffer $\mathrm{pH}$ was $\mathrm{pH}$ 8.0. This suggests that Aspergillus niger $65 \mathrm{I} 6$ produced an alkaline lipase from the Jatropha curcas seed cake medium, contrasting other studies which report that most lipases produced by Aspergillus are acidic (Pera et al., 2006; Shu et al., 2009; Mhetras et al., 2009; Toida et al., 1998). Alkaline lipases have

Table 2. Partial purification of lipase from Aspergillus niger $65 \mathrm{I} 6$ using anion exchange chromatography.

\begin{tabular}{ccccccc}
\hline No. & Fraction & $\begin{array}{c}\text { Total protein } \\
\mathbf{( m g )}\end{array}$ & $\begin{array}{c}\text { Total activity } \\
\mathbf{( U )}\end{array}$ & $\begin{array}{c}\text { Specific } \\
\text { activity } \\
\mathbf{( U / m g )}\end{array}$ & $\begin{array}{c}\text { Yield } \\
\mathbf{( \% )}\end{array}$ & $\begin{array}{c}\text { Purification } \\
\text { factor } \\
(\mathbf{- )}\end{array}$ \\
\hline 1. & Crude & 5.57 & 193.88 & 34.82 & 100 & 1 \\
2. & Anion Exchange & 0.39 & 166.9 & 421.97 & 86.11 & 12.1 \\
\hline
\end{tabular}


Hidayat et al.

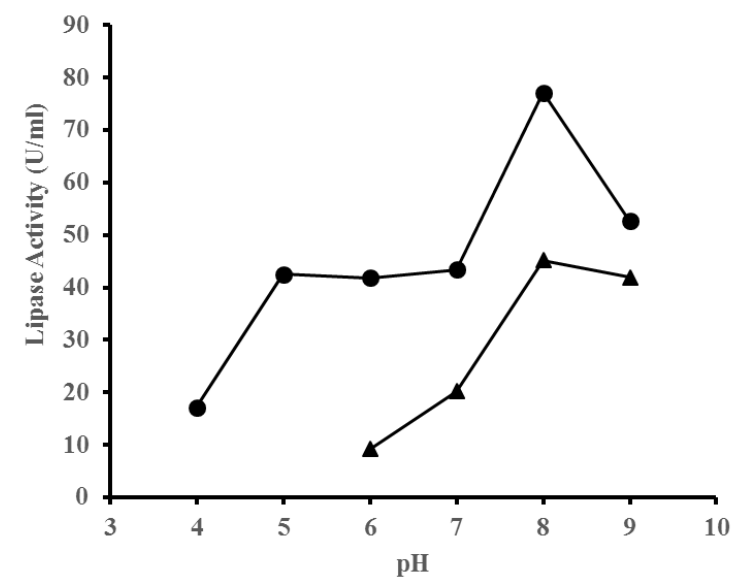

Fig. 1. Effect of $\mathrm{pH}$ buffer on hydrolytic (•) and esterification activity ( $\mathbf{\Delta})$ of Aspergillus niger 65 I6 lipase.

been reported from other strains, however, including Fusarium oxysporum (Prazeres et al., 2006; Rifaat et al., 2010), Fusarium solani (Maia et al., 1999), Penicillum chrysogenum (Cho et al., 2007), and Rhizopus chinensis (Sun and $\mathrm{Xu}, 2009)$.

The differing characteristics of the Aspergillus niger 65I6 lipase is probably related to the physiology of the microorganism. According to Ward et al. (2006), the activity of enzymes at certain $\mathrm{pH}$ values corresponds with the environmental $\mathrm{pH}$. It is to be expected that gene regulation is responsible for mediating this characteristic. Thus, the alkalinity of the lipase from Aspergillus niger 65I6 probably reflects its medium's environment, which supports its growth.

\section{Effect of Temperature on Aspergillus niger $65 I 6$ Lipase Activity}

Fig. 2 shows the effect of temperature on lipase activities. Hydrolytic activities increased about 1.2 times when the temperature increased from $30^{\circ} \mathrm{C}$ to $40{ }^{\circ} \mathrm{C}$. However, increasing the temperature to $50^{\circ} \mathrm{C}$ resulted in a decrease in hydrolytic activity by about 2.5 times, while an increase from $50{ }^{\circ} \mathrm{C}$ to $70{ }^{\circ} \mathrm{C}$ saw another slight decrease. Similarly, although to a smaller extent, esterification activity increased about 1.1 times when the temperature increased from $30^{\circ} \mathrm{C}$ to $40^{\circ} \mathrm{C}$, but decreased by about 2 times
I.J. Biotech, Vol. 20, No. 2

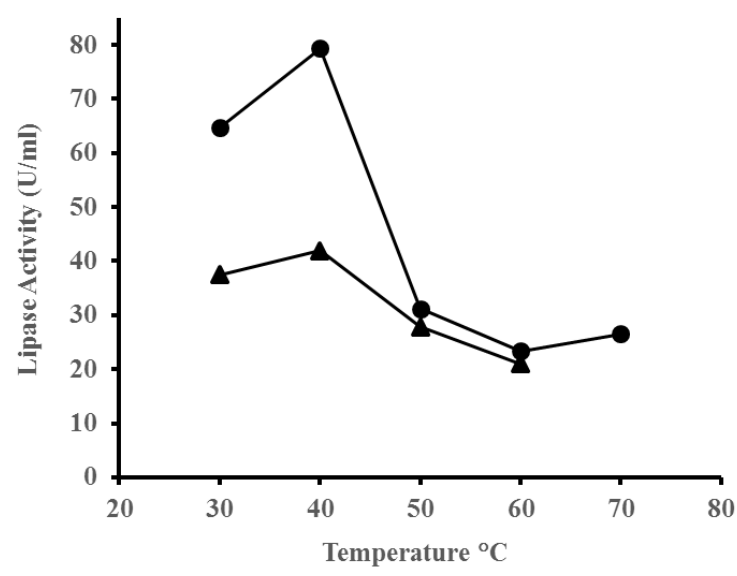

Fig. 2. Effect of temperature on the hydrolytic $(\bullet)$ and esterification activity ( $\boldsymbol{\Delta}$ ) of Aspergillus niger 65 I6 lipase.

with a temperature increase of $40^{\circ} \mathrm{C}$ to $60^{\circ} \mathrm{C}$. The optimum temperature for lipase activity was therefore $40^{\circ} \mathrm{C}$, suggesting that lipase from Aspergillus niger 65I6 is a mesophilic lipase. These results are similar to those of Falony et al. (2006), Ferrer et al. (2000), and Chahinian et al. (2000).

Temperature may affect the molecular structure of an enzyme along with its catalytic activity. The rate of enzymatic activity can double with every $10{ }^{\circ} \mathrm{C}$ increase in temperature (Copeland, 2000). However, the enzyme's activity rate will eventually decrease significantly as the result of denaturation. Thus, the decrease in lipase activity at temperatures above $40{ }^{\circ} \mathrm{C}$ was probably a reflection of thermal denaturation in the Aspergillus niger 65I6 lipase.

\section{Substrate Specificity of Lipase}

One of the characteristics of enzyme is substrate specificity. Since lipase has been used as a biocatalyst for the synthesis of biodiesel, the substrate specificity of the Aspergillus niger 65I6 lipase was evaluated. Fig. 3 shows that lipase hydrolyzed olive oil 2.06, 30, and 595 times faster compared with Jatropha oil, palm oil, and tributyrin, respectively. This indicates that Aspergillus niger 65I6 lipase has the specificity to hydrolyze long-chain triacylglycerols. The hydrolysis specificity can be seen from the 


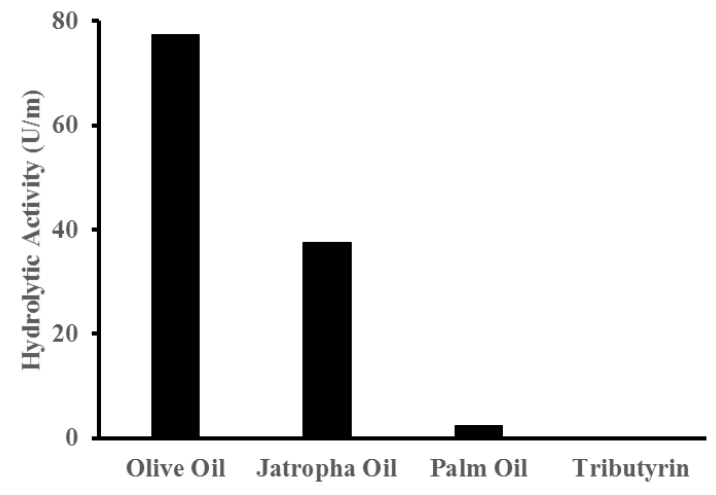

Fig. 3. Substrate specificity of lipase from Aspergillus niger 65I6.

fatty acids content of the triacylglycerols of the oils. The triacylglycerol of olive oil is composed mostly of long-chain fatty acids, containing $55-83 \%$ of oleic acid (C18:1) (Gunstone et al., 2007), whereas Jatropha oil contains $34-45 \%$ of oleic acid and $29-44 \%$ of linoleic acid (C18:2). Palm oil contains middle-chain triacylglycerols, such as lauric acids (48\%), while tributyrin contains shortchain triacylglycerols, such as butyric acid (C4). Tributyrin was the lowest substrate to be hydrolyzed by the Aspergillus niger 65I6 lipase. Thus, lipase from Aspergillus niger $65 I 6$ exhibited higher specificity to hydrolyze long-chain fatty acids from olive oil than any other substrate (Fig. 3).

\section{Stability of Aspergillus niger 65I6 Lipase in Organic Solvents}

Lipases catalyze reversible reactions, especially the hydrolysis and synthesis of ester bonds. The reactions are controlled by the availability of water in the reaction mixture. The synthesis reaction will occur only when the water availability in the reaction mixture is relatively low. Sometimes, organic solvents are added to increase the solubility of hydrophobic substrates. However, the enzymes are generally unstable during the addition of these organic solvents.

Fig. 4 shows that incubation of lipase in acetone resulted in a decrease in enzyme activity by about $50 \%$, while incubation in

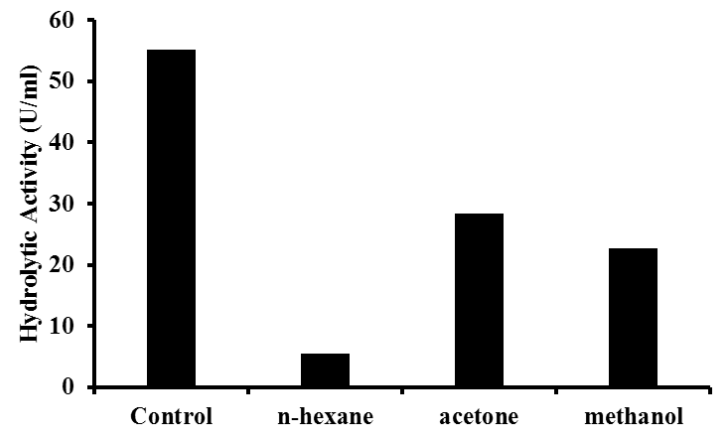

Fig. 4. Stability of lipase from Aspergillus niger $65 \mathrm{I} 6$ in various organic solvents.

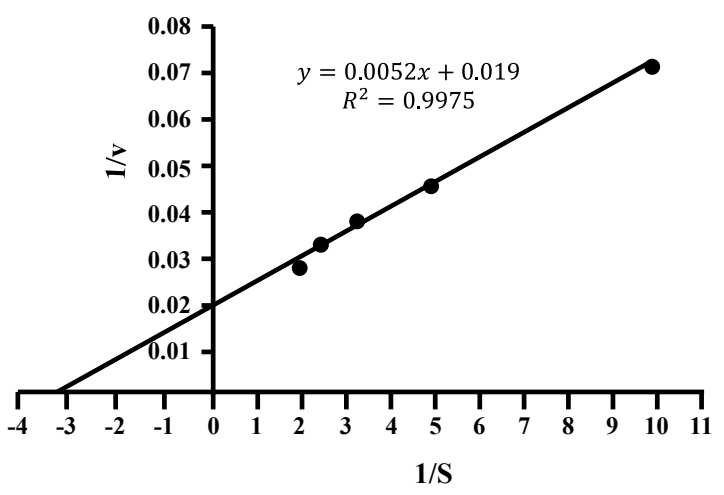

Fig. 5. Lineweaver-Burk or double reciprocal transformation of velocity against substrate concentration.

methanol resulted in a decrease in enzyme activity by about $60 \%$. The addition of a non-polar solvent, $\mathrm{n}$-hexane, resulted in a decrease in enzyme activity by $90 \%$. These results show that lipase from Aspergillus niger 65I6 had higher stability in a polar organic solvent compared with a non-polar organic solvent.

In general, the addition of a polar organic solvent has a more destabilizing effect than a non-polar organic solvent (Rifaat et al., 2010). Our findings were an exception, but in agreement with the results of Kukreja and Bera (2005), which showed that the addition of hexane might cause the loss of enzyme activity by up to $50 \%$, whereas the addition of acetone and methanol results in a loss of only about $10 \%$ in lipase from Pseudomonas aeruginosa. 
Hidayat et al.

\section{Kinetic Parameters}

Fig. 5 shows Lineweaver-Burk or double reciprocal transformation of velocity substrate concentration. These types of plots generate linear regressions and enable easier determination of the MichaelisMenten constant $\left(\mathrm{K}_{\mathrm{m}}\right)$ and maximum reaction velocity $\left(\mathrm{V}_{\max }\right)$. The results indicate that lipase activities followed simple MichaelisMenten kinetics. The apparent $\mathrm{K}_{\mathrm{m}}$ and $\mathrm{V}_{\max }$ were $0.27 \mu \mathrm{mol} / \mathrm{ml}$ and $52.63 \mu \mathrm{mol} / \mathrm{ml} / \mathrm{min}$, respectively.

\section{Conclusion}

With Jatropha curcas seed cake as the medium, lipase from Aspergillus niger 65I6 was produced using solid-state fermentation. One step purification using anion exchange resulted in an increase in specific activity from $34.82 \mathrm{U} / \mathrm{mg}$ to $421.97 \mathrm{U} / \mathrm{mg}$. The purification factor and lipase yield were 12.1 and $86.11 \%$, respectively. The results further showed that the lipase from Aspergillus niger 65I6 was alkaline, and the optimum $\mathrm{pH}$ and temperature for lipase activities were $\mathrm{pH} 8.0$ and $40^{\circ} \mathrm{C}$, respectively. The lipase had the specificity to hydrolyze long-chain fatty acids of acylglycerol. It was stable in the presence of polar organic solvents, specifically acetone of methanol. The apparent $\mathrm{K}_{\mathrm{m}}$ and $\mathrm{V}_{\max }$ of the Aspergillus niger 65I6 lipase were $0.27 \mu \mathrm{mol} /$ $\mathrm{ml}$ and $52.63 \mu \mathrm{mol} / \mathrm{ml} / \mathrm{min}$, respectively.

\section{References}

Abigor, R.D., Uadia, P.O., Foglia, T.A., Haas, M.J., Scott, K. and Savary, B.J. 2002. Partial Purification and Properties of Lipase from Germinating Seeds of Jatropha curcas L. JAOCS., 79, 1123-1126.

Akanbi, T.O. and Barrow, C.J. 2015. Lipasecatalysed incorporation of EPA into emu oil: Formation and characterisation of new structured lipids. J. Funct. Foods, $19,801-809$.

Aguieiras, E.C.G., Cavalcanti-Oliveira, E.D. and Freire, D.M.G. 2015. Current status and new developments of biodiesel production using fungal lipase. Fuel 159: 52-67.
I.J. Biotech, Vol. 20, No. 2

Alkan, H., Baysal, Z., Uyar, F. and Dogru, M. 2007. Production of lipase by a newly isolated bacillus coagulans under solidstate fermentation using melon wastes. Appl. Biochem. Biotechnol., 136,183-292.

Berchmans, H.J. and Hirata, S. 2008. Biodiesel production from crude Jatropha curcas L. seed oil with a high content of free fatty acids. Bioresour. Technol., 99, 1716-1721.

Bisen, P.S., Sanodiya, B.S., Thakur, G.S., Baghel, R.K. and Prasad, G.B.K.S. 2010. Biodiesel production with special emphasis on lipase-catalyzed transesterification. Biotechnol. Lett., 32, 1019-1030.

Bora, P.P., Bez, G. and Anal, J.M.H. 2011. First example of hydrolytic kinetic resolution of acrylate of secondary alcohols by lipase Amano AK. J. Mol. Catal. B-Enzym., 72, 270-275.

Bussamara, R., Fuentefria, A.M., de Oliveira, E.S., Broetto, L., Simcikova, M., Valente, P., Schrank, A. and Vainstein, M.H. 2010. Isolation of a lipase-secreting yeast for enzyme production in a pilot-plant scale batch fermentation. Bioresour. Technol., 101, 268-275.

Chahinian, H., Vanot, G., Ibrik, A., Rugani, N., Sarda, L. and Comeau, L.C. 2000. Production of extracellular lipase by Penicillum cyclopium purification and characterization of a partial acylglycerol lipase. Biosci. Biotechnol. Biochem., 64 (2), 215-222.

Cihangir, N. and Sarikaya, E. 2004. Investigation of lipase production by a new isolate of Aspergillus sp. World J. Microbiol. Biotechnol., 20, 193-197.

Cho, H.Y., Bancerz, R., Ginalska, G., Leonowicz, A., Cho N. S. and Ohga, S. 2007. Cultureconditions of psychrotrophic fungus Penicillium chrysogenum and its lipase characteristics. J. Fac. Agr., Kyushu Univ., 52 (2), 281-286

Cho, S.H., Wang, P.Y. and Tsai, S.W. 2011. Lipase-catalyzed hydrolytic resolution of (R,S)-3-hydroxy-3-phenylpropionates in biphasic media. J. Taiwan Inst. Chem. Eng., 42, 408-412. 
Chong, F.C., Tey, B.T., Dom, Z.M., Cheong, K.H., Satiawiharja, B., Ibrahim, M.N., Rahman, R.A., Biak, R.R.A. and Ling, T.C. 2007. Rice bran lipase catalyzed esterification of palm oil fatty acid distillate and glycerol inorganic solvent. Biotechnol. Bioprocess Eng., 12, 250-256.

Copeland, R.A. (2000). Enzymes: A practical introduction to structure, mechanism, and data analysis. New York: Wiley$\mathrm{VCH}$, Inc.

Damaso, M.C.T., Passianoto, M.A., Freitas, S.C., Freire, D.M.G., Lago, R.C.A. and Couri, S. 2008. Utilization of agroindustrial residues for lipase production by solid state-fermentation. Braz. J. Microbiol., 39, 676-681.

Ebongue, G.F.N., Dhouib, R., Carrière, F., Amvam Zollo, P.H. and Arondel, V. 2006. Assaying lipase activity from oil palm fruit (Elaeis guineensis Jacq.) mesocarp. Plant Physiol. Biochem., 44, 611-617.

Falony, G., Coca-Armas, J., Dustet-Mendoza, J.C. and Martinez-Hernández., J.L. 2006. Production of extracellular lipase from Aspergillus niger by solid-state fermentation. Food Technol. Biotechnol., 44 (2), 235-240.

Ferrer, M., Plou, F.J., Nuero, O.M., Reyes, F. and Ballesteros, A. 2000. Purification and properties of a lipase from Penicillium chrysogenum isolated from industrial wastes. J. Chem. Technol. Biotechnol., $75,569-576$.

Gombert, A.K., Pinto, A.L., Castilho, L.R. and Freire, D.M.G. 1999. Lipase production by Penicillium restrictum in solid state fermentation using babassu oil cake as substrate. Process Biochem., 35, 85-90.

Gunstone, F.D., Harwood, J.L. and Dijkstra, A.J. 2007. The lipid handbook. $3^{\text {rd }}$ edition. New York: CRC Press Taylor and Francis Group.

Gutarra, M.L.E., Godoy, M.G., Maugeri, F., Rodrigues, M.I., Freire, D.M.G. and Castilho, L.R. 2009. Production of an acidic and thermostable lipase of the mesophilic fungus Penicillium simplicissimum by solid-state fermentation. Bioresour. Technol., 100 (21), 5249-5524.

Hasan, F.A., Shah, A. and Hameed, A. 2006. Industrial Applications of Microbial Lipases. Enzyme Microb. Technol., 39, 235-251.

Kamini, N.R., Mala, J.G.S. and Puvanakrishnan, R. 1998. Lipase production from Aspergillus niger by solid-state fermentation using gingelly oil cake. Process Biochem., 33, 505-511.

Kempka, A.P., Lipke., N.L., Pinhero, T.L.F., Menoncin, S., Treicel, H., Freire, D.M.G., Di Luccio, M. and de Oliveira, D. 2008. Response surface method to optimize the production and characterization of lipase from Penicillium verrucosum in solidstate fermentation. Bioprocess Biosyst. Eng., 31, 119-125.

Khan, N.R. and Rathod, V.K. 2015 Enzyme catalyzed synthesis of cosmetic esters and its intensificational: A review. Process Biochem. 50: 1793-1806.

Kukreja, V. and Bera, M.B. 2005. Lipase from Pseudomonas aeruginosa MTCC 2488: partial purification and calcium dependent thermostability. Indian J. Biotechnol., 4, 222-226.

Mahapatra, P., Kumari, A., Garlapati, V.K., Banerjee, R. and Nag, A. 2011. Optimization of Process Variables for Lipase Biosynthesis from Rhizopus oligosporus NRRL 5905 Using Evolutionary Operation Factorial Design Technique. Indian J. Microbiol., 50 (4), 396-403.

Mahadik, N.D., Puntambekar, U.S., Bastawde, K.B., Khire, J.M. and Gokhale, D.V. 2002. Production of acidic lipase by Aspergillus niger in solid state fermentation. Process Biochem., 38 (5), 715-721.

Mahanta, N., Gupta, A., and Khare, S.K. 2008. Production of protease and lipase by solvent tolerant Pseudomonas aeruginosa PseA in solid-state fermentation using Jatropha curcas seed cake as substrate. Bioresour. Technol., 99, 1729-1735.

Maia, M.M.D., Morais, M. M.C., Morais, M.A., Melo, E.H.M. and Filho, J.L.L. 1999. 
Hidayat et al.

Production of extracellular lipase by the phytophatogenic fungus Fusarium solani FS 1. Rev. Microbiol., 30, 304-309.

Marseno, D.W., Indrati, R. and Ohta, Y. 1998. A simplified method for determination of free fatty acids for soluble and immobilized lipase assay. Indonesian Food Nutrition Progress, 5 (2), 79-83.

Mhetras, N.D., Bastawde, K.B. and Gokhale, D.V. 2009. Purification and characterization of acidic lipase from Aspergillus niger NCIM 1207. Bioresour. Technol., 100, 1486-1490

Pera, L.M., Romero, C.M., Baigori, M.D. and Castro, G.R. 2006. Catalytic properties of lipase extracts from Aspergillus niger. Food Technol. Biotechnol., 44 (2), 247-252.

Prazeres, J.N., Cruz, J. A. B. and Pastore, G.M. 2006. Characterization of alkaline lipase from Fusarium oxysporum and the effect of different surfactants and detergents on the enzyme activity. Braz. J. Microbiol., 37, 505-509.

Rifaat, H.M., El Mahalawy, A.A., El-Menofy, H.A. and Donia, S.A. 2010. Production, optimization and partial purification of lipase from Fusarium oxysporum. J. Appl. Sci. Env. Sanit., 5, 70-84.

Rodriguez, J.A., Mateos, J.C., Nungaray, J., Gonzalez, V., Bhagnagar, T., Roussos, S., Corvoda, J. and Baratti, J. 2006. Improving lipase production by nutrient source modification using Rhizopus homothallicus cultured in solid state fermentation. Process Biochem., 41, 2264-2269.

Shu, Z.Y., Yang, J.K. and Yan, Y.J. 2007. Purification and characterization of a lipase from Aspergillus niger F044. Chin. J. Biotechnol., 23(1), 96-100.

Silva, M.F., Freire, D.M.G., de Castro, A.M., DiLuccio, M., Mazutti, M.A., Oliveira, V., Treichel, H. and Oliveira, D. 2011. Production of multifunctional lipases by Penicillium verrucosum and Penicillium brevicompactum under solid state fermentation of babassu cake and castor meal. Bioprocess Biosyst. Eng., 34, 145-152.
I.J. Biotech, Vol. 20, No. 2

Sun, S. and Xu, Y. 2009. Membrane-bound 'synthetic lipase' specifically cultured under solid-state fermentation and submerged fermentation by Rhizopus chinensis: a comparative investigation. Bioresour. Technol., 100, 1336-1342.

Toida, J., Arikawa, Y., Kondou, K., Fukuzawa, M. and Sekiguchi, J. 1998. Purification and characterization of triacylglycerol lipase from Aspergillus oryzae. Biosci. Biotechnol. Biochem., 62 (4), 759-763.

ul-Haq, I., Idrees, S. and Rajoka, M.I. 2002. Production of lipases by Rhizopus oligosporous by solid-state fermentation. Process Biochem., 37, 637-641.

Vokhlu, J. and Kour, A. 2006. Yeast lipases: enzyme purification, biochemical properties and gene cloning. Electronic J. Biotechnol., 9 (1), DOI: 10.2225/vol9issue1-fulltext-9.

Ward, O.P., Qin, W.M., Dhanjoon, J., Ye, J. and Singh, A., 2006. Physiology and biotechnology of Aspergillus. Adv. Appl. Microbiol., 58, 1-75.

Zang, K.P., Lai, J.Q., Huang, Z.L. and Yang, Z. 2011. Penicillium expansum lipasecatalyzed production of biodiesel in ionic liquid. Bioresour. Technol., 102, 2767-2772. 